\title{
The 2-Ga peraluminous magmatism of the Jacobina- Contendas Mirante belts (Bahia, Brazil): Geologic and isotopic constraints on the sources
}

\author{
Pierre Sabaté ${ }^{1}$, Moacyr M. Marinho ${ }^{2}$, Philippe Vidal ${ }^{3}$ and \\ Michelle Caen-Vachette ${ }^{3}$ \\ ${ }^{1}$ ORSTOM, Paris (France) and Instituto de Geociências, UFBA, 40161 Salvador (BA) (Brazil) \\ ${ }^{2}$ Companhia Baiana de Pesquisa Mineral (CBPM), Centro Administrativo da Bahia, 41500 Salvador (BA) (Brazil) \\ ${ }^{3}$ CNRS and Blaise Pascal University, F-63038 Clermont-Ferrand (France)
}

(Accepted for publication February 2, 1990)

\begin{abstract}
Sabaté, P., Marinho, M.M., Vidal, Ph. and Caen-Vachette, M., 1990. The 2-Ga peraluminous magmatism of the JacobinaContendas Mirante belts (Bahia, Brazil): Geologic and isotopic constraints on the sources. In: B.K. Nelson and Ph. Vidal (Guest-Editors), Development of Continental Crust through Geological Time, Chem. Geol., 83: 325-338.

A 500-km north-south alignment of granitic intrusions cross-cuts the central part of the São Francisco craton. These late- to post-tectonic granitic bodies are emplaced between two Archean blocks (Jequié and Gavião blocks) and cross-cut the Contendas Mirante volcano-sedimentary sequence and the metasedimentary rocks of the Serra de Jacobina. They are two-mica or muscovite-garnet-bearing peraluminous granites.

$\mathrm{Rb}-\mathrm{Sr}$ systematics show that these granites were emplaced during the Transamazonian orogeny $(\sim 1.9 \mathrm{Ga})$. The high initial ${ }^{87} \mathrm{Sr} /{ }^{86} \mathrm{Sr}$ ratios $(0.706-0.748)$ and the very low $\epsilon_{\mathrm{Nd}(t)}(-13$ to -5$)$ indicate a crustal origin. The possible sources are: (1) the Jequié block; (2) the Contendas Mirante sequence; and (3) the Gavião block, including some early Archean domes [trondhjemitic-tonalitic-granodioritic (TTG), Boa Vista type] which were tectonically emplaced within the volcano-sedimentary sequence.

The currently available $\mathrm{Rb}-\mathrm{Sr}$ and $\mathrm{Sm}-\mathrm{Nd}$ data are not consistent with reworking of the 3.5-Ga TTG. The combination of field and isotopic constraints preclude the Jequié block and the Contendas Mirante sequence and favour instead the Gavião block medium-grade terrains as the source for the peraluminous granitic line.

The available data suggest that a continent-continent collision occurred during the Transamazonian orogeny, which followed subduction/obduction marked by volcanism (arc-tholeiitic, calc-alkaline and shoshonitic) and related plutonism.
\end{abstract}

\section{Introduction}

The São Francisco craton (Almeida, 1967; Almeida et al., 1977) provides an excellent area to study crust formation events that occurred during the transition between the Archean and Proterozoic $(\sim 2.5 \mathrm{Ga})$ and the orogenic processes that operated during the lower-middle Proterozoic ( $\sim 2 \mathrm{Ga})$. The São Francisco craton is one of the main remnants of the Archean and early Proterozoic crust of South America. The part of this structural province (Almeida et al., 1981) which consolidated at $1.7 \mathrm{Ga}$ is mainly exposed in Bahia state.

Available geochronologic data (Marinho et al., 1979, 1980; Brito Neves et al., 1980; Cordani et al., 1985) recently synthesized by Mascarenhas and Garcia (1987), and supplemented (Wilson, 1987; Wilson et al., 1988) indicate a remarkable succession of igneous events from 3.5 to $1.9 \mathrm{Ga}$. In addition, a long alignment of 2-Ga-old peraluminous leucogranites (Himalayan-type) marks the limit between the Jequié block and the Gavião block. 
This boundary is also marked by low- to medium-grade supracrustal fold belts. The existence of good indicators of a continent-continent collision, such as high-grade metamorphism (Newton, 1987) and leucogranites (Le Fort, 1981), in addition to the existence in the Jequié block of a lower Proterozoic arc series metamorphosed in the granulite facies (Barbosa, 1986), indicates that a continent-continent collision occurred around $2 \mathrm{Ga}$ following subduction under the Jequié block.

The goals of the present work were: (1) to determine the absolute chronology of the magmatic episodes; (2) to identify the sources of the different magmas; and ( 3 ) to constrain the geodynamic processes that occurred during the Transamazonian orogeny.

\section{Geologic setting}

The main Archean to Proterozoic features of the São Francisco craton in Bahia state, Brazil, may be summarized by three commonly accepted units (Fig. 1).

(1) High-grade terrains form the Jequié block and its mobile belts (Mascarenhas, 1973, 1979) extend for $>700 \mathrm{~km}$ from north to south, and correspond to the Salvador Curaça and the Atlantic Coast or Itabuna granulitic belts, respectively (Fig. 2).

(2) A medium-grade gneiss-migmatitic complex forms the large western band of these older terrains (Gavião block) and a northeastern nucleus in the middle Itapicuru river region.

(3) Supracrustal sequences, metamorphosed in the greenschist to amphibolite facies, are associated with the medium-grade gneiss migmatitic complex (Fig. 2). They correspond to the volcano-sedimentary belts of Jacobina and Contendas Mirante as well as less extensive occurrences.

\subsection{High-grade terrains}

The high-grade terrains consist of granulitefacies charnockites, enderbites, and a volcano- sedimentary sequence. In the Atlantic Coast belt (Fig. 2), Barbosa (1986) presented evidence for volcanic series similar to modern island arc associations. The distribution of the arc tholeiites, and the calc-alkaline and the shoshonite metavolcanics of these series suggests an early subduction system preceding the strong deformation and granulitic metamorphism. This subduction system is also recognized by Figueiredo (1989) on the basis of geochemical data.

\subsection{Medium-grade terrains}

The medium-grade terrains occupy roughly the western part of the São Francisco craton and correspond to the Gavião block (Fig. 1). The separated nucleus of the middle Itapicuru river in the northeastern part of the craton, now juxtaposed with the Salvador Curaça granulitic belt, has similar lithologies and metamorphic history, and is related to the Gavião block.

The terrains are composed of an assemblage of various gneiss-amphibolite associations, which include migmatites and plutonic rocks. Some of the gneiss formations are paragneiss, but most of the gneiss-leptite-amphibolite piles are considered as volcanic and volcanoclastic or volcano-sedimentary sequences. The plutonic rocks are widely distributed in the gneiss migmatite complex. Among them a 3.13.5-Ga trondhjemitic-tonalitic-granodioritic (TTG) association forms huge massifs such as Lagoa do Morro, Sete Voltas, Boa Vista, etc. (Fig. 2), which probably represent the oldest lithologies of the craton (Cordani et al., 1985).

The rocks were deformed by tectonic events during the Archean and Proterozoic. The latter is mainly marked by E-W shortening, associated with westward thrusting and crustal thickening related to the last migmatitic processes (Sabaté et al., 1988).

\subsection{Supracrustal sequences}

The most representative supracrustal sequences are located along the junction be- 


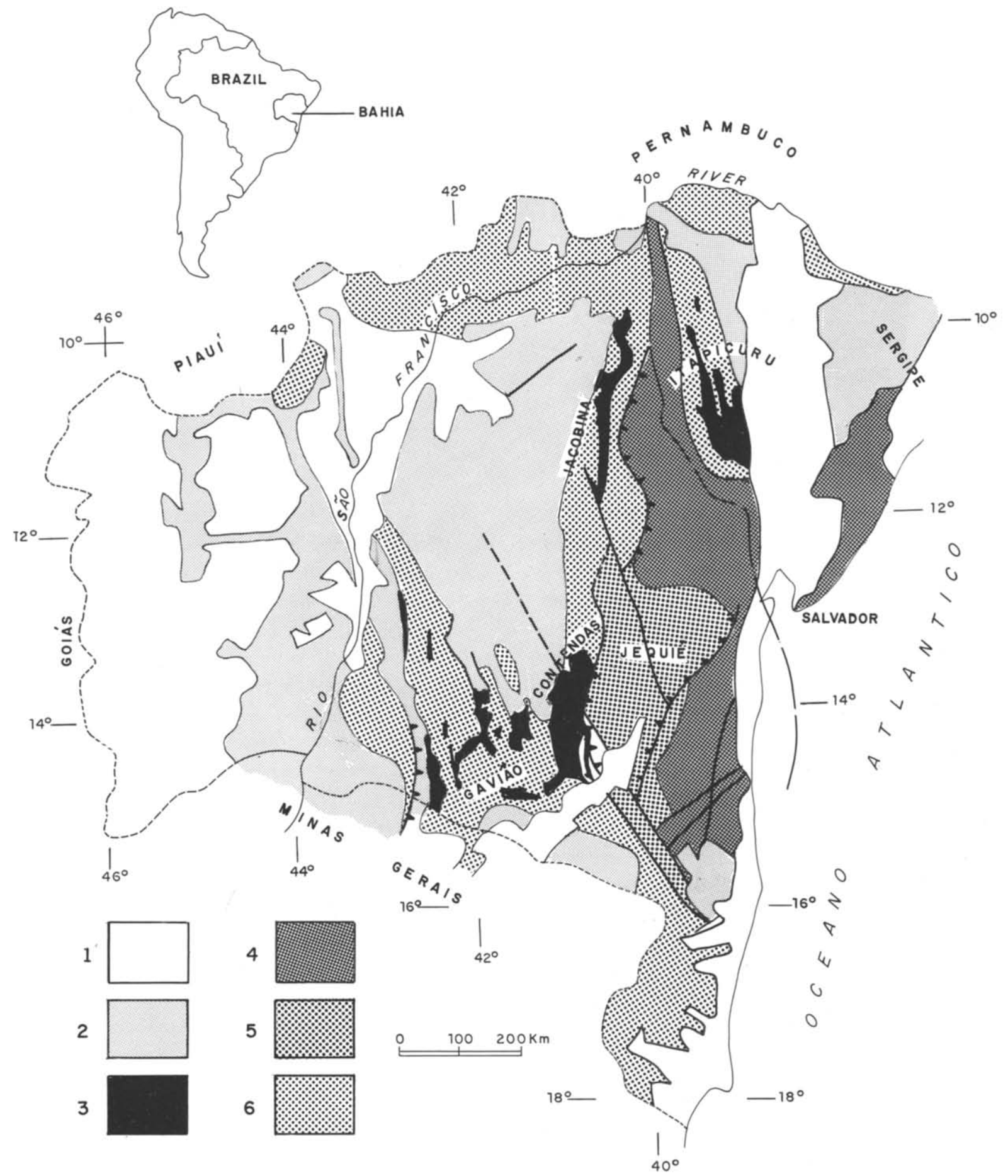

Fig. 1. Structural outline of Bahia state. [ $I=$ Phanerozoic cover; $2=$ Brazilian and Pre-Brazilian covers (São Francisco and Espinhaço super groups); $3=$ Archean to early Proterozoic supracrustal complexes (volcano-sedimentary and greenstone belts); $4=$ Archean to early Proterozoic mobile belt (granulites, charnockites, migmatites and gneiss); $5=$ Jequié granulitic complex (granulite facies volcano-sedimentary cover, charnockites and enderbites); $6=$ Archean gneiss-migmatitic and granitic complex ]. Modified from Mascarenhas (1976). 


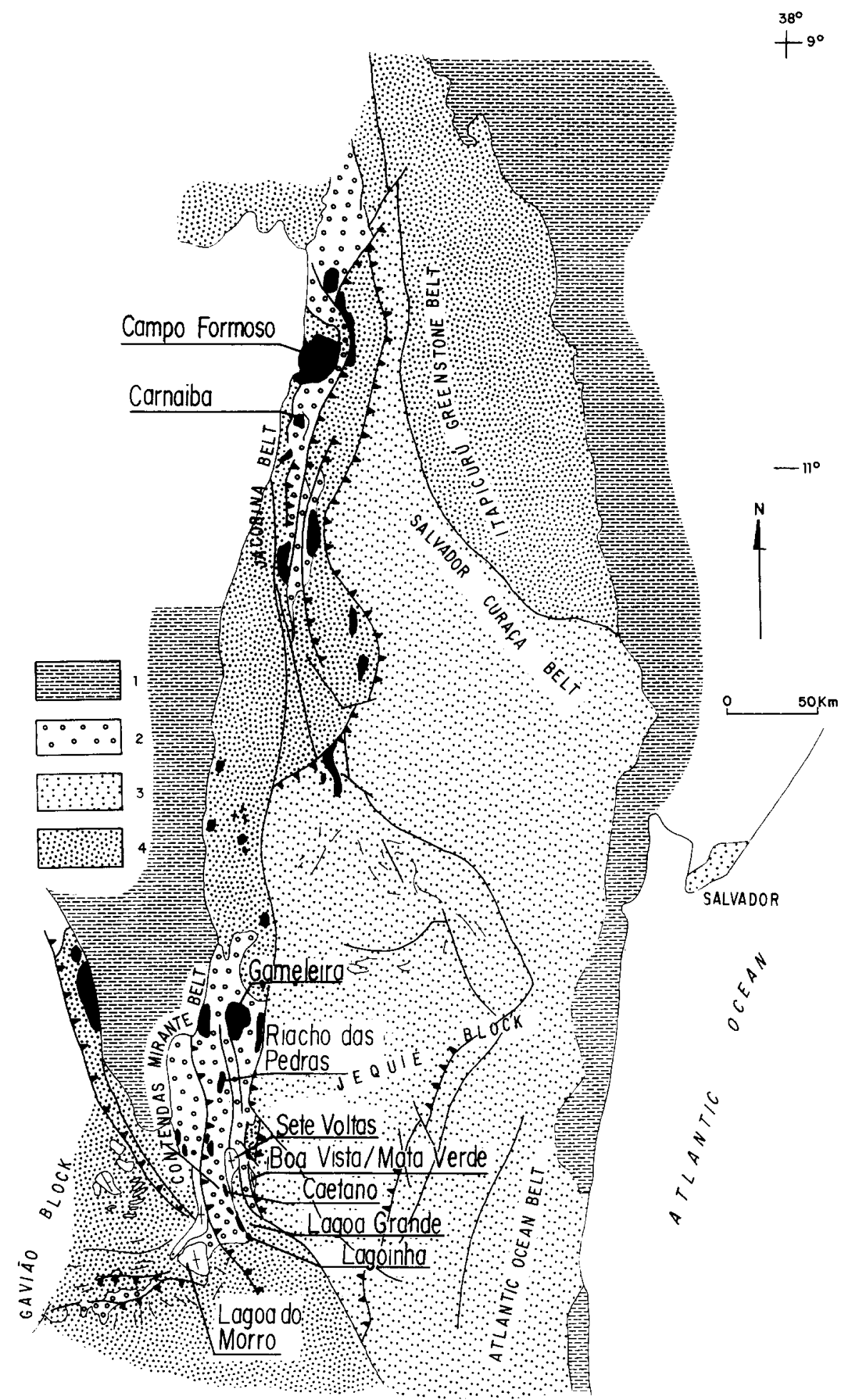

Fig. 2. Tectonic sketch map of the junction zone of the Gavião block and the Jequié block. Location of the studied intrusions relative to the main structures. $1=$ Phanerozoic and middle and upper Proterozoic covers and belt; $2=$ volcanosedimentary belts; $3=$ high-grade terrains; Jequié block granulitic formations and Archean to early Proterozoic mobile belts; 4 = Gavião block medium-grade formations; the late- to post-tectonic Transamazonian granitoids are dark; the older (Archean) and syn-tectonic (early Transamazonian event) plutons are shown by a cross. 
tween the two Archean blocks and form the main meridian alignment of Contendas Mirante and Jacobina belts (Figs. 1 and 2). Some remnants of sequences somewhat analogous to the former are encountered into the Gavião block (Fig. 1). Each of these belts is associated with plutonic rocks.

\subsubsection{Contendas Mirante belt. The volcano-} sedimentary sequence of Contendas Mirante is composed of two stratigraphic units (Marinho et al., 1979, 1980). The lower unit contains almost all the volcanogenic components. These are basalts and intermediate metavolcanics intercalated with detrital and chemical sediments. The upper unit is essentially detrital. The rocks are metamorphosed in the greenschist facies grading to the amphibolite facies at the proximity of its eastern tectonic contact with the Jequié block. The two units are deformed by two principal phases (Sabaté et al., 1980 ). The first is isoclinal recumbent, with a west vergence and is accompanied by a westward overthrusting. The second is marked by E-W shortening which upturns the previous structures and progressively transforms the westward tangential movement into sub-horizontal N-S transcurrent shearing. With these phases, segments of the Gavião block are uplifted in the Contendas Mirante belt and its imbricated Gavião block segments.

\subsubsection{The Jacobina belt. the metasedimentary} Jacobina sequence is mainly made up of detrital epicontinental sediments. Some ultramafics are intercalated in the tectonic edifice. The rocks are metamorphosed in the amphibolite facies. The structure of the belt corresponds to imbricated slices which also show westward vergence. As in the Contendas Mirante belt, the subsequent shortening and upturning led the tangential movement to be transformed to subhorizontal N-S shearing. In the resulting framework, a large overthrusted imbricated slice related to the Gavião block separates the
Jacobina belt from the Salvador Curaça mobile belt (Figs. 1 and 2).

\section{The plutonic rocks}

All these belts are intruded by several plutonic associations which are described as belonging to two distinct groups.

The Jacobina and Contendas Mirante belts are the locus of a remarkable up to $500-\mathrm{km}$ alignment of syn- to late-tectonic granites that emphasize the axial shear zone and the borders of the belts. More than fifteen bodies are recognized as related to the Contendas Mirante belt (Marinho et al., 1979, 1980; Marinho and Sabaté, 1982; Conceição, 1986) and up to seven related to the Jacobina belt (Couto, 1978; Rudowski et al., 1987; Celino and Sabaté, 1988). Some bodies can also be seen in the same tectonic alignment between the two belts (Fig. 2) in the Itaberaba region (Fernandes and Sabaté, 1987; Giuliani et al., 1988 ). All of the plutons are peraluminous and show various degrees of differentiation (Conceição, 1986; Rudowski, 1989).

Seven areas were chosen for the present work:

- Five are located in the axial zone of the Contendas Mirante belt. From north to south they are the Gameleira, Riacho das Pedras, Caetano, Lagoa Grande and Lagoinha bodies.

- The composite Campo Formoso massif and the Carnaiba body are situated in the Jacobina belt.

\subsection{Gameleira massif}

The Gameleira is the largest peraluminous body of the axial line intrusions of the Contendas Mirante belt (Fig. 2). In the vicinity of the Jequié block, it intruded the volcano-sedimentary sequence where it induced a thermal metamorphism that developed cordierite and andalusite in the country rock. Its emplacement is synchronous with the late and important overprinting folding phase (Sabaté et al., 
1980) which represents shortening related to the crustal thrusting.

The mean composition is granodioritic with a quartz-oligoclase-andesine-microcline assemblage showing wide variations in relative proportions of the phases. The index mineral is a red-brown, green or sometimes bleached biotite. Muscovite may be abundant. It is generally deuteric, formed at expense of the Kfeldspar and plagioclase. Microcline is also present. The accessory minerals are zircon, apatite, titanite, magnetite-ilmenite and secondary epidote.

\subsection{Riacho das Pedras intrusion}

The Riacho das Pedras granite (Fig. 2) is late tectonic relative to the folding phases and the accompanying overthrusting. It consists of a hololeucocratic granite associated with a network of aplite and pegmatite dikes that crosscut the sequence. The fine- to medium-grained granite is made up of quartz, albite and microcline. Muscovite may be abundant. The biotite is subordinate and sometimes absent. Apatite, magnetite, hematite, zircon and rare titanite are the typical accessory minerals, with less commonly tourmaline and garnet. The two latter minerals, especially tourmaline, are common in the related pegmatites and aplites.

\subsection{Caetano, Lagoa Grande and Lagoinha bodies}

The Caetano, Lagoa Grande and Lagoinha intrusions form elongate bodies (20, 10 and 4 $\mathrm{km}$ long, respectively) aligned along the axial shear zone of the Contendas Mirante belt. A narrow band of supracrustals separate them form the large N-S Archean dome of Sete Voltas (Fig. 2). Their emplacement is synchronous (Lagoinha, Lagoa Grande) to late (Caetano) with respect to the shearing.

The plutons consist of leucogranite with a two-mica \pm garnet association. They have muscovite layering (Caetano), and schlieren with biotite (Caetano), biotite + garnet (Lagoa Grande), and biotite+muscovite (Lagoinha). Aplopegmatitic dikes or pockets with biotite, muscovite and tourmaline are associated.

\subsection{Campo Formoso massif and Carnaiba body}

The Campo Formoso massif is the most important intrusion in the Jacobina belt. It represents a multi-stage intrusion with several successive, roughly concentric, peraluminous granitic facies, and a suite of aplite and pegmatite dikes (Rudowski et al., 1987). Three successive main types are recognized ( $\mathrm{Ru}$ dowski, 1988): (1) a coarse-grained to porphyritic muscovite-rich granite; (2) a medium- to fine-grained two-mica granite and (3) a muscovite-garnet-albite granite with only relicts of biotite. In these three types, zircon and apatite are the common accessories. Garnet, tourmaline and beryl characterize the associated quartz-albite-microcline aplopegmatite suite.

Muscovite crystallized during several stages of the magmatic evolution. The early crystallization developed during the stage corresponding to the acquisition of the preferred orientation by the plutonic bodies. The muscovite also formed during the deuteric stage, and accompanies late shear zones or fills microfissures.

The Carnaiba body is a small circular intrusion composed of two types of granites corresponding to types (2) and (3) of Campo Formoso.

Chemically, all the granitic facies are peraluminous. Based on trace-element and rareearth element (REE) behaviour, Rudowski (1988) distinguishes two "series": one corresponding to the two-mica granite (type 2) which leads by differentiation to the muscovite-garnet granite, and the other to a suite of muscovite granites (type 1 ) marked by subsolidus transformations. The chemical character- 
teristics suggest a heterogeneous magmatic source (Rudowski, 1989).

\section{Geologic constraints on the sources}

The structural evolution indicates that peraluminous plutonism accompanied continent-continent collision marked by overthrusting and subsequent shortening that terminated with transcurrent shearing.

The presence in the Gameleira massif of mica-rich garnet-bearing xenoliths, which may represent the residual phase of partial melting, led Petta (1979) to attribute the source rocks to the neighbouring blocks. The overthrusting of the Jequié block previous to or synchronous with the intrusion rules out the Jequié block alternative for the source, and restricts the source to within the Gavião block formations and/or the volcano-sedimentary sequence.

For the Riacho das pedras granite, as for the similar bodies of the axial Contendas Mirante line (Caetano, Lagoa Grande, Lagoinha), a crustal source is assumed by Marinho and Sabaté (1982) on the basis of the peraluminous and sodi-potassic paragenesis, and confirmed by the very high ${ }^{87} \mathrm{Sr} /{ }^{86} \mathrm{Sr}$ ratio $(\sim 0.768)$ obtained during a previous dating program (Sato, 1982; Cordani et al., 1985). Compared with the Gameleira intrusion, they probably had the same petrogenesis. Crystallization occurred under conditions corresponding to the mesozone and epizone where mica and cordierite are in equilibrium, implying a high water pressure. Thus, the rocks must have crystallized relatively close to their source regions. However, the migration of leucogranitic magmas could have been more extensive because of higher fluid pressure linked to the presence of boron, which reduces both the solidus temperature and the magma viscosity (Pichavant, $1984,1987)$. This is suggested as much by the petrographic associations, with its abundant pegmatite suites, as by the presence of tourmaline. Consequently, the source is less likely to have been in the Contendas Mirante for- mations than in either the Gavião block or the Jequié high-grade lithotypes.

The structural framework clearly shows the presence of Gavião block terrains as infrastructure to the Contendas Mirante edifice. The geologic configuration of the leucogranitic intrusion line located on the western border of the Gavião block segment uplifted into the Contendas Mirante belt, and their chronologic relation as syn- to late-tectonic relative to the transcurrent shearing following overthrusting, rule out the possibility that the Jequie block is a good candidate for the source of the granites. In addition, the granulitic metamorphism, which is related to continental collision (Newton, 1987), and, in the case of the Jequié block, is approximately synchronous with leucogranite intrusion (Wilson, 1987; Wilson et al., 1988 ), indicates that the Jequié block should separated in space from the peraluminous granite production zone. Thus the potential sources probably are in the non-granulitic formations of the Gavião block. Similarly, the chronologic and tectonic setting of the peraluminous diapirs of Campo Formoso and Carnaiba, and their field relations with the medium-grade gneiss-migmatites related to the Gavião block, support the Gavião terrains as a possible source and rule out involvement of the granulitic Jequié block. The deep metasedimentary Jacobina sequence, intruded by the granites may also have contributed to their genesis.

Are the supracrustals a possible source for the granites? The lower unit of the Contendas Mirante sequence is composed of ultramafics, mafics, carbonate rocks and banded iron formations, and consequently is not a good candidate. The clastic sediments, tuffs and graywacke of the upper unit are a possible source; however, they are cross-cut by the granites and are located in the emplacement zone of the massifs, not in the source zone of the magma. The total absence of mafic enclaves and the geochemical patterns (Rudowski, 1989; $\mathrm{Cu}$ ney et al., 1990) tend to exclude a mantle 
source. The composition of all the granites, which is very close to the ternary minimum of the granitic system, and the absence of fractionated crystallization suites (Cuney et al., 1990 ) support the hypothesis of magma production exclusively by crustal melting. Alternatively, Cuney et al. (1990) show that the mineralogical and chemical features of these granites reflect the dominantly meta-igneous character of the source and propose the Archean TTG as the possible source material.

\section{Isotopic study}

\subsection{Analytical techniques}

$\mathrm{Sr}$ and $\mathrm{Nd}$ isotopic compositions have been obtained in Clermont-Ferrand, on a VG54E ${ }^{\circledR}$ mass spectrometer using the procedures described by Pin and Carme (1987). During the course of the experiments, NBS 987 and La Jolla standards gave ${ }^{87} \mathrm{Sr} /{ }^{86} \mathrm{Sr}$ and ${ }^{143} \mathrm{Nd} /{ }^{144} \mathrm{Nd}$ of $0.71025 \pm 0.00004$ and $0.51186 \pm 0.00003$, respectively (the quoted errors represent the external reproducibility at $2 \sigma$ on $10 \mathrm{Sr}$ runs and $8 \mathrm{Nd}$ runs ). Sm and $\mathrm{Nd}$ were obtained by isotope dilution with a precision of $\pm 1 \%$ on their ratio. $\mathrm{Rb}$ and $\mathrm{Sr}$ were obtained by $\mathrm{X}$-ray fluorescence spectrometry (XRF) with a precision of $\pm 2 \%$ on their ratio.

\subsection{Results}

Five granites were dated using the $\mathrm{Rb} / \mathrm{Sr}$ whole-rock isochron technique. The data are reported in Table I and in Fig. 3. Three of the granites (Campo Formoso, Gameleira and Riacho das Pedras) yield well-defined isochrons and cluster in the age range of 1.93-1.97 $\mathrm{Ga}$. The isochrons for the two other granites are based only on three samples and need confirmation, although it is probably not fortuitous that the age of the Lagoinha-Lagoa Grande granite lies within the same range as the others. The Caetano data plot below the Lagoinha-Lagoa Grande isochron, and may
TABLE I

$\mathrm{Rb}-\mathrm{Sr}$ isotopic data for Bahia Transamazonian peraluminous granites

\begin{tabular}{|c|c|c|c|c|}
\hline Sample & $\begin{array}{l}\mathrm{Rb} \\
(\mathrm{ppm})\end{array}$ & $\begin{array}{l}\mathrm{Sr} \\
(\mathrm{ppm})\end{array}$ & ${ }^{87} \mathrm{Rb} /{ }^{86} \mathrm{Sr}$ & ${ }^{87} \mathrm{Sr} /{ }^{86} \mathrm{Sr}$ \\
\hline
\end{tabular}

\begin{tabular}{lcrcr}
\hline \multicolumn{5}{c}{ Campo Formoso granite: } \\
6 & 230 & 167 & 4.040 & 0.82143 \\
13 & 265 & 153 & 5.067 & 0.85094 \\
$22 \mathrm{c}$ & 265 & 129 & 6.058 & 0.87784 \\
180 & 320 & 121 & 7.808 & 0.92704 \\
88 & 289 & 105 & 8.148 & 0.93140 \\
$54 \mathrm{~A}$ & 274 & 93 & 8.697 & 0.94536 \\
29 & 285 & 89 & 9.542 & 0.98643 \\
$62 \mathrm{~A}$ & 371 & 71 & 15.90 & 1.16032 \\
$48 \mathrm{C}$ & 282 & 30.3 & 29.050 & 1.52168 \\
$48 \mathrm{~B}$ & 342 & 37.0 & 28.847 & 1.50898
\end{tabular}

Carnaiba granite:

$\begin{array}{lllll}\text { CA5 } & 350 & 90.7 & 11.53 & 1.04894 \\ \text { CA9 } & 404 & 92.0 & 13.16 & 1.08494 \\ \text { CA16 } & 460 & 64.0 & 22.08 & 1.33340\end{array}$

Riacho das Pedras granite:

$\begin{array}{lrrcr}99 \mathrm{D} & 215 & 13.5 & 53.03 & 2.25953 \\ 99 \mathrm{H} & 281 & 6.0 & 211.9 & 6.53939 \\ 99 \mathrm{I} & 134 & 14.5 & 28.89 & 1.54825 \\ 99 \mathrm{~J} & 334 & 5.5 & 349.6 & 10.48640 \\ 99 \mathrm{~K} & 311 & 5.6 & 291.2 & 8.96639 \\ 99 \mathrm{~B} & 200 & 14.5 & 44.68 & 1.96824 \\ 99 \mathrm{C} & 215 & 14.4 & 49.07 & 2.08941 \\ 99 \mathrm{~F} & 214 & 15.5 & 44.89 & 2.01100 \\ 99 \mathrm{M} & 327 & 4.8 & 417.8 & 12.22670\end{array}$

Gameleira granite:

$\begin{array}{llrll}91 \mathrm{~A} & 271 & 146 & 5.429 & 0.86052 \\ 92 & 225 & 172 & 3.828 & 0.81478 \\ 95 & 282 & 161 & 5.129 & 0.84709 \\ 96 & 259 & 94 & 8.124 & 0.93353 \\ 97 \mathrm{~B} & 276 & 146 & 5.582 & 0.86737 \\ 101 & 275 & 114 & 7.114 & 0.90776 \\ 11218 & 342 & 148 & 6.790 & 0.89570\end{array}$

Lagoa Grande-Lagoinha-Caetano granite:

\begin{tabular}{lcccc} 
GO9HC-BC & 243 & 76 & 9.430 & 0.97237 \\
G54HC & 205 & 182 & 3.300 & 0.80295 \\
G58HC & 173 & 248 & 2.028 & 0.76428 \\
CAE2 & 66.0 & 31.0 & 6.241 & 0.84683 \\
\hline
\end{tabular}

reflect disturbance during the Brazilian event. In addition, the Carnaiba granite is very probably the source of fluids that developed the emerald-rich metasomatic zones in the enclos- 

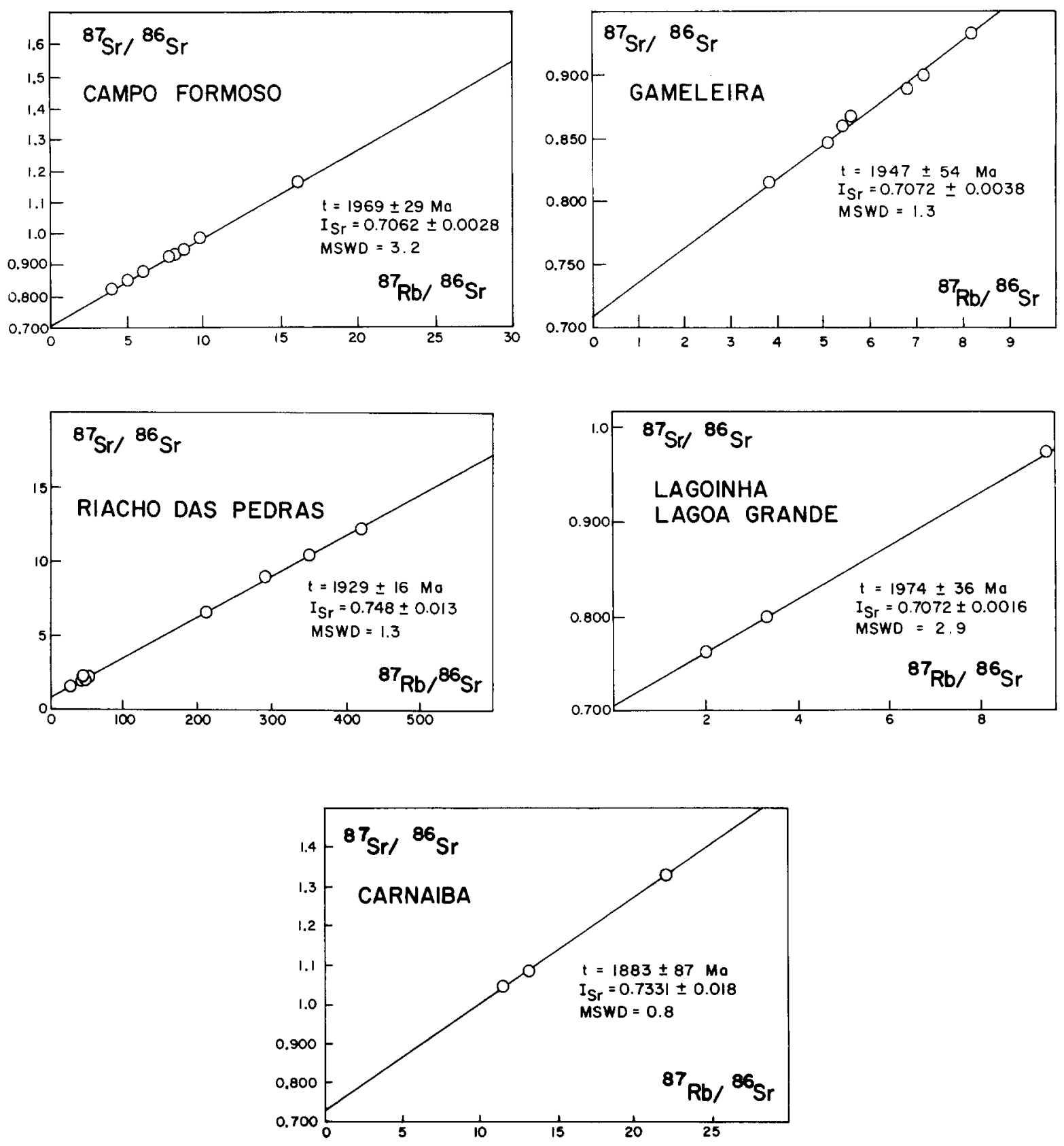

Fig. 3. Rb-Sr isochron diagrams for the Bahia Transamazonian peraluminous granites. $I_{\mathrm{Sr}}=$ initial $\mathrm{Sr}$ ratio $=\left({ }^{87} \mathrm{Sr} /{ }^{86} \mathrm{Sr}\right)_{i}$.

ing serpentinites (Rudowski, 1989). Rb-Sr dating of these zones provided an age of $1.869 \pm 0.028 \mathrm{Ga}$ (L. Rudowski, Ph. Vidal and M. Caen-Vachette, in prep.) which is within error of the 1.88-Ga age obtained on the Carnaiba granite. Therefore, the Carnaiba granite probably represents a late-magmatic event subsequent to the main phase of the Transamazonian emplacement between 1.97 and 1.93 $\mathrm{Ga}$.

The ${ }^{87} \mathrm{Sr} /{ }^{86} \mathrm{Sr}$ initial ratios of the granites are much higher than the mantle ratio at the time of their production (Fig. 4). This indicates that they were formed by melting of materials hav- 


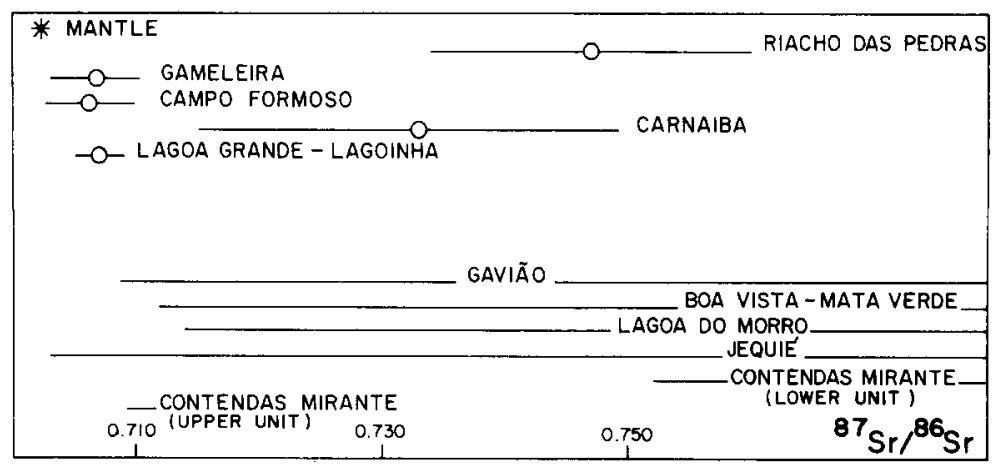

Fig. $4 .{ }^{87} \mathrm{Sr} /{ }^{86} \mathrm{Sr}$ vs. time for Bahia Transamazonian granitoids and their potential source rocks. The field of the source rocks have been drawn using the data of Cordani et al. (1985) and M.M. Marinho (unpublished data, 1988).

ing had a significant crustal residence time. To consider potential sources, the range of ${ }^{87} \mathrm{Sr} /$ ${ }^{86} \mathrm{Sr}$ ratios (corrected for $1.95 \mathrm{Ga}$ and using their extreme $\mathrm{Rb} / \mathrm{Sr}$ ratios and isotopic composition) of the various formations exposed in this part of the São Francisco craton have been plotted in Fig. 4. The field for Boa Vista-Sete Voltas and Lagoa de Morro TTG, the Gavião block migmatites and granitoids, and the Jequié high-grade rocks are rather well constrained (Cordani and Iyer, 1978; Cordani et al., 1985; Wilson, 1987). In contrast, the RbSr characteristics of the Contendas Mirante volcano-sedimentary sequence are poorly constrained. We have reported in Fig. 4 the few available data for the formations which could, from petrologic arguments, possibly be good candidates for the granitic source, i.e. the phyllites of the upper unit and the felsic metavolcanics of the lower unit (Cordani et al., 1985; Wilson, 1987). The Gameleira, Campo Formoso and Lagoa Grande-Lagoinha granites match only the Jequié and Gavião fields, whereas the origin is less constrained for the Riacho das Pedras and Carnaiba granites. However, for the Riacho das Pedras granite, its very high initial $\mathrm{Sr}$ isotopic ratio (0.747) might not be that of the source because this highly evolved magma had exceedingly high $\mathrm{Rb} / \mathrm{Sr}$ ratios. The ${ }^{87} \mathrm{Sr} /{ }^{86} \mathrm{Sr}$ ratio can increase very rapidly during the magmatic stage itself (Vidal et al., 1979). High initial ratios also have been proposed to result from exchange with country rocks through convective cells (Bonin et al., 1987). However, there is no indication of hydrothermal activity or low-temperature changes in granite mineralogy.

In conclusion, $\mathrm{Sr}$ isotopes alone cannot identify with precision the source rocks. In addition, it must be recalled that despite the fact that $\mathrm{Sr}$ isotope geochemistry indicates that all granitoids possess a crustal signature, the exact characteristics of their sources are impossible to deduce by $\mathbf{R b}-\mathrm{Sr}$ systematics since variable $\mathrm{Rb} / \mathrm{Sr}$ ratios can be produced by partial melting of a given source without changing ${ }^{87} \mathrm{Sr} /$ ${ }^{86} \mathrm{Sr}$.

In contrast to $\mathrm{Sr}$ isotopes, $\mathrm{Nd}$ isotopes are more straightforward to interpret because Sm/ $\mathrm{Nd}$ ratio fractionation during partial melting is much smaller and more confidently modelled. The Sm-Nd results are given in Table II. The calculated $\epsilon_{\mathrm{Nd}(t)}$-values are negative $(-13$ to -5$)$ and confirm the crustal origin of the granitoids as inferred from $\mathrm{Sr}$ isotopes. The time of first extraction of the material out of the mantle can be obtained by calculating model ages relative to the depleted mantle. Ages range between 2421 and $3165 \mathrm{Ma}$. The case of Riacho das Pedras granite $\left(t_{\mathrm{DM}}=3165\right.$ $\mathrm{Ma}$ is peculiar. It exhibits very high $\mathrm{Rb} / \mathrm{Sr} \mathrm{ra}-$ tios, low REE contents and high Sm/Nd ratios. These features are typical of highly evolved granites. In this case, the $\mathrm{Sm} / \mathrm{Nd}$ ratio 
TABLE II

Sm-Nd isotopic data for Bahia Transamazonian peraluminous granites $t_{\mathrm{DM}}$ is calculated using $\left({ }^{143} \mathrm{Nd} /{ }^{144} \mathrm{Nd}\right)_{i}=0.513114$ and ${ }^{147} \mathrm{Sm} /{ }^{144} \mathrm{Nd}=0.222$ (Ben Othman et al., 1984)

\begin{tabular}{llllllrr}
\hline Sample & Granitoids & $\begin{array}{l}\mathrm{Sm} \\
(\mathrm{ppm})\end{array}$ & $\begin{array}{l}\mathrm{Nd} \\
(\mathrm{ppm})\end{array}$ & ${ }^{147} \mathrm{Sm} /{ }^{144} \mathrm{Nd}$ & ${ }^{143} \mathrm{Nd} /{ }^{144} \mathrm{Nd}$ & $\epsilon_{\mathrm{Nd}(t)}$ & $\begin{array}{l}t_{\mathrm{DM}} \\
(\mathrm{Ma})\end{array}$ \\
\hline 11217 & Riacho das Pedras & 0.55 & 2.02 & 0.1646 & 0.51191 & -6.2 & 3,165 \\
11218 & Gameleira & 4.1 & 27.2 & 0.09111 & 0.51087 & -8.8 & 2,600 \\
GO9HC-BC & Lagoinha & 4.1 & 17.5 & 0.1420 & 0.51169 & -4.9 & 2,698 \\
G58HC & Lagoa Grande & 2.5 & 15.6 & 0.0966 & 0.51097 & -7.6 & 2,592 \\
CAE2 & Caetano & 1.47 & 10.03 & 0.0889 & 0.51099 & -5.2 & 2,421 \\
6 & Campo Formoso & 5.81 & 41.1 & 0.08536 & 0.51057 & -13.1 & 2.821 \\
13 & Campo Formoso & 4.07 & 25.5 & 0.09646 & 0.51101 & -7.4 & 2,541 \\
\hline
\end{tabular}

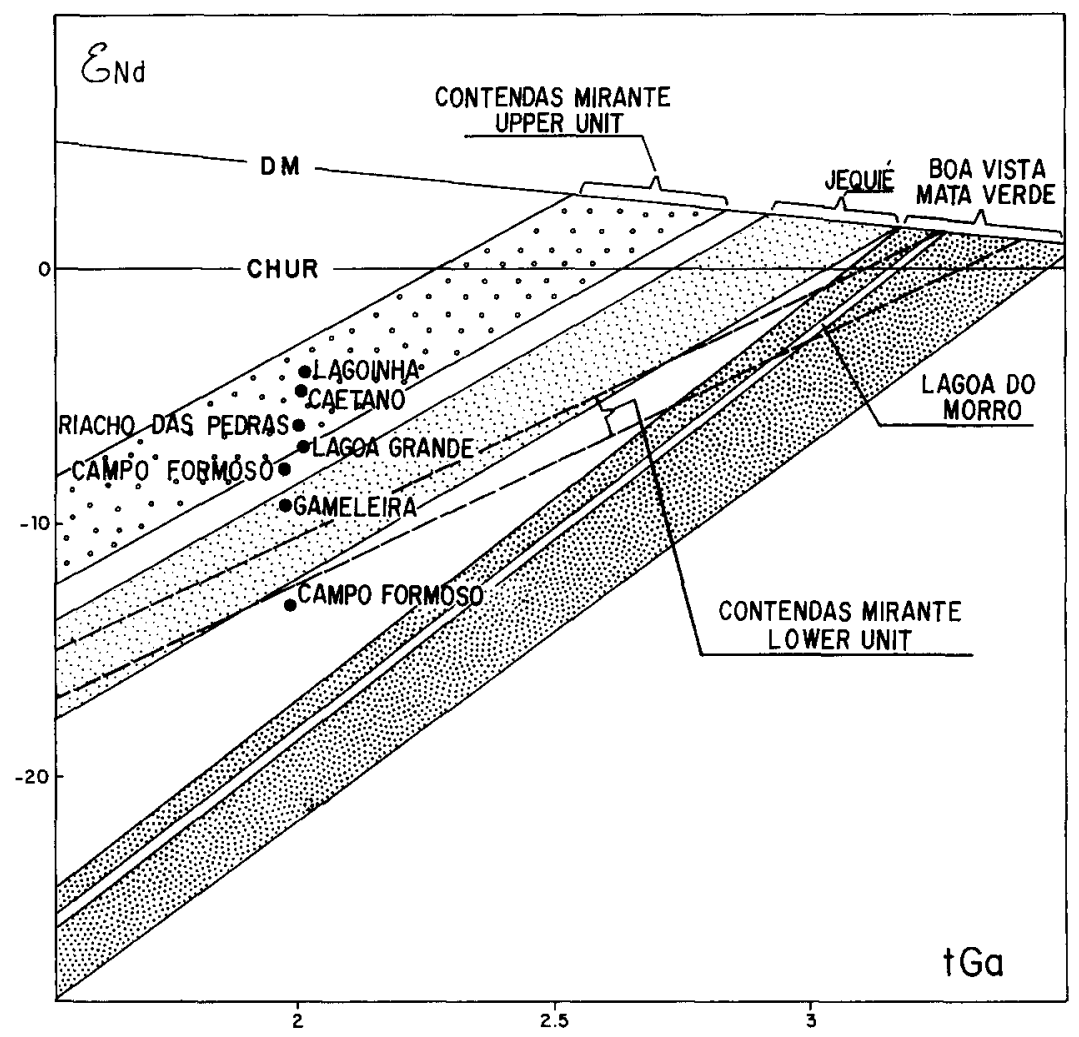

Fig. 5. Nd vs. time for Bahia Transamazonian granitoids and their potential source rocks. The field of the source rocks have been drawn using the data of Wilson (1987) and M.M. Marinho (unpublished data, 1988).

of the magma can be increased with respect to the source by retaining monazite in the partial melting residue, or removing it during an early stage of the magmatic history. This situation can lead to a gross overestimation of the model ages (Vidal et al., 1984; Vidal, 1987). Instead, using a typical crustal REE pattern (e.g., shale pattern) for the source provides a source age in agreement with the other granitoids.

The age of the sources, the close grouping of 
$t_{\mathrm{DM}}$ between 2.4 and $2.8 \mathrm{Ga}$, and comparison of the $\epsilon_{\mathrm{Nd}(t)}$ of the granites with their potential sources (Fig. 5) (data from Wilson, 1987; M.M. Marinho, unpublished data, 1988), strongly support the hypothesis that the crust that has produced these granitoids by partial melting is neither the 3.5-Ga-old Boa VistaMata Verde orthogneisses nor the 3.1-Ga-old Lagoa do Morro orthogneisses (which originally belonged to the Gavião block). Instead the sources must be late Archean in age.

\subsection{Discussion}

Although Nd isotopes are consistent with the felsic rocks from the Contendas Mirante sequence (upper and/or lower unit) as the source of the Transamazonian peraluminous granites (Fig. 5), the hypothesis is ruled out by structural constraints. The same conclusions are reached for the Jequié block formations.

In addition, isotopic data also show that the old TTG cannot be considered as a good candidate for the source. Therefore, the only possible source left is the late Archean migmatized gneiss-amphibolites and granitoids of the Gavião block. These fit the structural, petrologic and $\mathrm{Sr}$ isotope constraints. Although there are no $\mathrm{Nd}$ isotopic data available yet, at the present time this is the best working hypothesis.

Finally, in the attempt to relate the production of the peraluminous granites to a continent-continent collision, the similarity in the isotopic characteristics of the Transamazonian and Himalayan granites is striking. In both cases, very low $\epsilon_{\mathrm{Nd}(t)}$-values are observed which implies essentially a crustal contribution. The only difference is the apparent isotopic homogeneity in the Transamazonian granites suggested by the good straight line of the data points in the $\mathrm{Rb}-\mathrm{Sr}$ isochron diagrams. This differs strongly from the Himalayan situation (Vidal et al., 1982; Deniel et al., 1987). This could simply be due to an "aging effect" (Vidal et al., 1985) which tends to wipe out the initial isotopic heterogeneities. $\mathrm{Nd}$ iso- topes are far less sensitive to this effect. This is reflected in the Campo Formoso granite where the two analyzed samples have different $\epsilon_{\mathrm{Nd}(t)}$.

\section{Acknowledgements}

The results presented in this paper constitute a contribution of the CNRS-INSU program "Dynamique et Bilan de la Terre" and of the project "Granitóides da Bahia: geologia e metalogênese" which receives financial support through agreements FINEP (PADCT)/ UFBA, CNPq/ORSTOM, SGM-SME (Ba)/ UFBA and CNEN/UFBA.

The authors thank J. de F. Mascarenhas (SGM-SME Bahia) for helpful discussions in the field and L. Rudowski for donating the samples of the Campo Formoso and Carnaiba massifs. We also especially thank B. Auvray, H. Martin, B. Nelson and three anonymous reviewers for useful criticism and comments and I. McReath for helpful discussions and revision of the English text.

\section{References}

Almeida, F.F.M. de, 1967. Origem e evolução da plataforma brasileira. Dep. Nac. Prod. Min., Div. Geol. Min., Bol. 241, 36 pp.

Almeida, F.F.M. de, Hasui, Y., Brito-Neves, B.B. de and Fuck, R.A., 1977. Províncias estruturais brasileiras. $8^{\circ}$ Symp. Geol. Nordeste, Campina Grande, Atas, Soc. Bras. Geol., pp. 363-391.

Almeida, F.F.M. de, Hasui, Y., Brito-Neves, B.B. de and Fuck, R.A., 1981. Brazilian structural provinces: an introduction. In: J.M. Mabesoone, B.B. de Brito-Neves and A.N. Sial (Editors), The Geology of Brazil. EarthSci. Rev., 17: 1-130.

Barbosa, J.S., 1986. Constitution lithologique et métamorphique de la région granulitique du sud de Bahia, Brésil. Doct. Thesis, University of Paris VI, Mém. Sci. Terre, Paris, No. 86-34, 401 pp.

Ben Othman, D., Fourcade, S. and Allègre, C.J., 1984. Recycling processes in granite-granodiorite complex genesis: the Querigut case studied by $\mathrm{Nd}-\mathrm{Sr}$ isotope systematics. Earth Planet. Sci. Lett., 69: 290-300.

Bernard-Griffiths, J., Peucat, J.J., Sheppard, S.M.F. and Vidal, Ph., 1985. Petrogenesis of Hercynian leucogranites from the Southern Armorican Massifs: Contribution of REE and isotopic ( $\mathrm{Sr}, \mathrm{Nd}, \mathrm{Pb}, \mathrm{O})$ geochemical data to the study of source rocks 
characteristics and ages. Earth Planet. Sci. Lett., 74: 235-250.

Bonin, B., Platevoet, B. and Vialette, Y., 1987. The geodynamic significance of alkaline magmatism in the Western Mediterranean compared with West Africa. Geol. J., 22: 361-387.

Brito-Neves, B.B. de, Cordani, U.G. and Torquato, J.R.F., 1980. Evolução geológica do Precambriano no Estado da Bahia. In: H.A.V. Inda (Editor), Geologia e recursos minerais do Estado da Bahia, Vol. 3. CPM/SME (Coord. Prod. Miner./Secr. Minas Energ.) Bahia, Salvador, pp. 1-101.

Celino, J.J. and Sabaté, P., 1988. O Maciço de Jaguarari: uma intrusão granítica de vocação crustal na margem do cinturão transamazônico da Serra de Jacobina (Bahia, Brasil). VII Congr. Lat.-Am. Geol., Belém, Abstr. Vol., p. 437.

Conceição, H., 1986. Os granitos do Rio Caveira: Petrologia de intrusões Precambrianas no cisalhamento axial do complexo Contendas Mirante (Bahia-Brasil). Dissertation, Mestrado, Univ. Feder. Bahia, Salvador (unpublished).

Cordani, U.G. and lyer, S.S., 1978. Geochronological investigation on the Precambrian granulitic terrains of Bahia, Brazil. Precambrian Res., 9: 255-274.

Cordani, U.G., Sato, K. and Marinho, M.M., 1985. The geologic evolution of the ancient granite-greenstone terrane of central-southern Bahia, Brazil. Precambrian Res., 27: 187-213.

Couto, P.A., 1978. Projeto Serra de Jacobina. Relatório Fin., DNPM-CPRM (Dep. Nac. Prod. Miner.-Comp. Pesqui. Recurs. Miner. ), Salvador, Vol. 1.

Cuney, M., Sabaté, P., Vidal, Ph., Marinho, M.M. and Conceiçao, H., 1990. The $2 \mathrm{Ga}$ peraluminous magmatism of the Jacobina-Contendas Mirante belts (Bahia, Brazil): major and trace elements geochemistry and metallogenic potential. In: P. Le Fort (Guest Editor), Collision Magmatisin. J. Volcanol. Geotherm. Res. (special issue; in press).

Deniel, C., Vidal, Ph., Fernandez, A., Le Fort, P. and Peucat, J.J., 1987. Isotopic study of the Manaslu granite (Himalaya, Nepal): inferences on the age and source of Himalayan leucogranite. Contrib. Mineral. Petrol., 96: 78-92.

Fernandes, P.C. d'A. and Sabaté, P., 1987. Condicionamento estrutural das intrusões proterozóicas a Molibdenita de Itaberaba e Pedra d'Agua (Bahia-Brasil). $1^{\circ}$ Simp. Nac. Estudos Tectônicos, Univ. Feder. Bahia, Salvador, Abstr. Vol., pp. 67-68.

Figueiredo, M.C.H., 1989. Geochemical evolution of eastern Bahia-Brasil: A probable early Proterozoic subduction-related magmatic arc. J. South Am. Earth Sci., 2(2): 147-154.

Giuliani, G., Fernandez, P.C. d'A and Rudowski, L., 1988. The Archean and Proterozoic molybdenum mineralizations of the Bahia State, Brazil: metallogenic impli- cations. VII Congr. Lat. Am. Geol., Belém, Abstr. Vol., p. 349.

Le Fort, P., 1981. Manaslu leucogranite: a collision signature of the Himalaya, a model for its genesis and emplacement. J. Geophys. Res., 86(B11): 1054510568.

Marinho, M.M. and Sabaté, P., 1982. The ContendasMirante volcano-sedimentary sequence and its granitic-migmatitic basement. In: International Symposium on Archean and Early Proterozoic Geologic evolution and Metallogenesis, Vol. 1, CPM/SME (Coord. Prod. Miner./Secr. Minas Energ.) Bahia, Salvador, Abstr. Excurs., pp. 139-184.

Marinho, M.M., Silva, E.F.A. da, Soares, J.V. and Costa, P.H., 1979. Projeto Contendas-Mirante. Comp. Baiana Pesqui. Miner. Conv. CPBM (Comp. Baiana Pesqui. Miner.)/SME (Secr. Minas Energ.) Bahia, Salvador, Relatório Fin., Vol. 1 (unpublished).

Marinho, M.M., Silva, E.F.A. da, Lopes, G.A.D.C., Soares, J.V. and Cruz, M.J.M., 1980. Projeto Anagé-Caldeirao. Comp. Baiana Pesqui. Miner. Conv. CBPM/SME (Comp. Baiana Pesqui. Miner./Secr. Minas Energ.) Bahia, Salvador, Relatório Fin., Vol. 1 (unpublished).

Mascarenhas, J. de F., 1973. A geologia do centro-leste da Bahia. An. 27 Congr. Bras. Geol., Aracaju, Soc. Bras. Geol., 2: 35-66.

Mascarenhas, J. de F., 1976. Geologia da region centro oriental da Bahia: Projeto Bahia, II. Sul da Bahia. CPRM, Conv. DNPM/CPRM (Dep. Nac. Prod. Miner./Comp. Pesqui. Recurs. Miner. ), Salvador, Relatório Fin., 1 vol., maps.

Mascarenhas, J. de F., 1979. Evolução geotectônica do Precambriano do Estado da Bahia. CPM/SME (Coord. Prod. Miner./Secr. Minas Energ.) Bahia, Geol. Rec. Min. Est. Bahia, Salvador, Textos Básicos, 2: $57-165$.

Mascarenhas, J. de F. and Garcia, T.W., 1987. Mapa geocronólogico do Estado da Bahia, 1/1.000.000 - Texto explicativo. SGM-SME (Superintend. Geol. Recurs. Miner.-Secr. Minas Energ.) Bahia, Salvador.

McReath, I. and Sabaté, P., 1987. Granitoids of the state of Bahia, Brazil: A review. Proc. Int. Symp. on Granites and Associated Mineralizations. Rev. Bras. Geociênc., 17: 404-414.

Newton, R.C., 1987. Petrologic aspects of Precambrian granulite facies terrains: bearing on their origins. In: A. Kröner (Editor), Proterozoic Lithosphere Evolution. Am. Geophys. Union, Geodyn. Ser., 17: 11-26.

Petta, R.A., 1979. Geoquímica do granito de Gameleira e suas relações com o embasamento na bacia do médio Rio de Contas, Bahia Brasil. Dissertation, Mestrado, Univ. Feder. Bahia, Salvador (unpublished).

Pichavant, M., 1984. The effect of boron on liquidus phase relationships in the system $\mathrm{Qz}-\mathrm{Ab}-\mathrm{Or}-\mathrm{H}_{2} \mathrm{O}$ at $1 \mathrm{kbar}$. Eos (Trans. Am. Geophys. Union), 65: 298 (abstract). Pichavant, M., 1987. Petrogenesis in lithophile-rich mag- 
mas. Int. Symp. on Granites and Associated Mineralisation. SGM-SME (Superintend. Geol. Recurs. Miner.-Secr. Minas Energ.) Bahia, Salvador, Extend. Abstr., Vol., pp. 139-141.

Pin, C. and Carme, F., 1987. Sm-Nd isotopic study of 500 Ma old oceanic crust in the Variscan belt of Western Europe: the Chamrousse ophiolite complex Western Alps (France). Contrib. Mineral. Petrol., 96: 406-413.

Rudowski, L., 1988. Pétrologie et géochimie des séries évolutives de granites peralumineux des massifs de Campo Formoso et Carnaiba et leurs relations avec les minéralisations à émeraudes (Serra de Jacobina, Bahia, Brésil). An. VII Congr. Lat.-Am. Geol. Belém, 1: 567575.

Rudowski, L., 1989. Pétrologie et géochimie des granites transamazoniens de Campo Formoso et de Carnaiba (Bahia, Brésil) et des phlogopitites à émeraude associées. Doct. Thesis, University of Paris VI, Mém. Sci. Terre, Paris, No. 89-15, 282 pp.

Rudowski, L., Giuliani, G. and Sabaté, P., 1987. Les phlogopitites à émeraudes au voisinage des granites de Campo Formoso et Carnaiba (Bahia-Brésil): un exemple de minéralisations à $\mathrm{Be}, \mathrm{Mo}$ et $\mathrm{W}$ dans des ultrabasites métasomatisées. C.R. Acad. Sci., Paris, 304, Sér. II, 18: 1129-1134.

Sabaté, P., Machado, G.V.M., da S. and Souza, M.Z.A. de, 1980. Données structurales des formations précambriennes épimétamorphiques du complexe Contendas-Mirante (Bahia, Brésil). Cah. ORSTOM (Off. Rech. Sci. Tech. Outre-mer), Paris, Sér. Géol. XI(1): 18-24.

Sabaté, P., McReath, I. and Giuliani, G., 1987. Plutonic associations of North-East Bahia. Int. Symp. on Granites and Associated Mineralizations. SGM-SME (Superintend. Geol. Recurs. Miner.-Secr. Minas Energ.) Bahia, Salvador, Excursion Guides Vol., pp. 91-124.

Sabaté, P., Gomes, L.C.C. and Anjos, J.A.A., dos, 1988.
Nota explicativa do mapa temático "Granitogênese da Bahia" - folha a 1/250.000 Vitória de Conquista. SGM-SME (Superintend. Geol. Recurs. Miner.-Secr. Minas Energ.) Bahia, Salvador, 1 coloured map (sheet printed, leaflet in press ).

Sato, K., 1982. Programa de datações geocronológicas do Estado da Bahia. Conv. SME (Secr. Minas Energ.) Bahia, USP/CPGEO (Univ. São Paulo/Cent. Pesqui. Geocronol.), 1978, s.n.t. relatõrios internos ).

Vidal, Ph., 1987. Use and misuse of radiogenic isotopes in granite petrology. Proc. Int. Symp. on Granites and Associated Mineralizations. Rev. Bras. Geociênc., 17: 468-472.

Vidal, Ph., Dosso, L., Bowden, P. and Lameyre, J., 1979. Strontium isotope goechemistry in syentie-alkaline granite complexes. In: A. Ahrens (Editor), Origin and Distribution of the Elements. Pergamon, Oxford, pp. 223-231.

Vidal, Ph., Cocherie, A. and Le Fort, P., 1982. Geochemical investigations of the origin of the Manaslu leucogranite (Himalaya, Nepal). Geochim. Cosmochim. Acta, 46: 2279-2292.

Vidal, Ph., Bernard-Griffiths, J., Cocherie, A., Le Fort, P., Peucat, J.J. and Sheppard, S.M.F., 1984. Geochemical comparison between Himalayan and Hercynian leucogranites. Phys. Earth Planet. Inter., 35: 179-190.

Wilson, N., 1987. Combined Sm-Nd, $\mathrm{Pb}-\mathrm{Pb}$ and $\mathrm{Rb}-\mathrm{Sr}$ geochronology and isotope geochemistry in polymetamorphic precambrian terrains: Examples from Bahia, Brazil and Channel Island, U.K. M.Sc. Thesis, Oxford University, Oxford (unpublished).

Wilson, N., Moorbath, S., Taylor, P.N. and Barbosa, J.S., 1988. Archean and Early Proterozoic crustal evolution in the São Francisco Craton, Bahia, Brazil. Eur. Assoc. Geochem., Int. Congr. of Geochemistry and Cosmochemistry, Paris, Chem. Geol., 70: 146 (abstract; special issue). 